\title{
Dynamics and limitations of phytoplankton biomass along a gradient in Mwanza Gulf, southern Lake Victoria (Tanzania)
}

\author{
I. J. M. CORNELISSEN ${ }^{*}{ }^{+}$, G. M. SILSBE ${ }^{\ddagger}$, J. A. J. VERRETH*, E. VAN DONK ${ }^{+, \S}$ AND \\ L. A. J. NAGELKERKE* \\ *Aquaculture and Fisheries group, Wageningen University, Wageningen, The Netherlands \\ ${ }^{+}$Netherlands Institute of Ecology (NIOO-KNAW), Wageningen, The Netherlands \\ ${ }^{\ddagger}$ Netherlands Institute of Sea Research (NIOZ-YE), Yerseke, The Netherlands \\ ${ }^{\S}$ Department of Ecology and Biodiversity, University of Utrecht, Utrecht, The Netherlands
}

\section{SUMMARY}

1. We investigated how dynamics in phytoplankton biomass are driven through light and nutrient limitations in the Mwanza Gulf, Lake Victoria (Tanzania).

2. We measured light attenuation, chlorophyll $a$ and water quality parameters along a phytoplankton biomass gradient in the Mwanza Gulf at six sampling stations in three different seasons from August 2009 to March 2011.

3. We found a higher rate of attenuation of photosynthetic available radiation than in other gulfs of Lake Victoria which could only partially be explained by phytoplankton biomass, measured as chlorophyll $a$. Suspended particulate detritus strongly affected light attenuation, particularly in shallow water.

4. In shallow water in the southern part of the Mwanza Gulf, nutrients were in excess and phytoplankton biomass was limited by light. In deeper water near the entrance of the gulf, light was not limiting when nitrogen probably was, as indicated by the N:P ratio.

5. Low abundance of $\mathrm{N}$-fixing phytoplankton species suggests that $\mathrm{N}$-fixation was low in shallow water. Phytoplankton biomass was lower in Mwanza Gulf than in northern gulfs of Lake Victoria, but might increase in the future as a result of nutrient enrichment caused by an increase in intensive agriculture and rapid growth of the city of Mwanza.

Keywords: eutrophication, lakes, physical environment, phytoplankton, primary production

\section{Introduction}

Lake Victoria has undergone major ecological changes since the 1960s. Its faunal composition changed with the introduction of Nile perch, Lates niloticus in the 1950s and 1960s, when the dominant endemic haplochromine cichlid fishes declined and hundreds of species went extinct (Witte et al., 1992; Goudswaard, Witte \& Katunzi, 2008). An important commercial fishery targeting Nile perch developed and peaked in 1990 with an estimated maximum total yield of 300000 ton per year. Catches now fluctuate around 230000 tons per year (Kolding et al., 2008).
In addition to the Nile perch and its fishery, another major driver of change in Lake Victoria is eutrophication, which started gradually from the 1920s onwards and which was caused by an increasing human population around the lake and corresponding degradation of the shorelines (Hecky, 1993). As a result of the increasing nutrient load into the lake, phytoplankton biomass increased and the community shifted from dominance of diatoms to cyanobacteria (Hecky, 1993; Mugidde, 1993; Kling, Mugidde \& Hecky, 2001; Verschuren et al., 2002; Stager et al., 2009; Sitoki et al., 2010). The increased primary production fuelled the food web and increased lake productivity and fish catches (Kolding et al., 2008;

Correspondence: Leo Nagelkerke, Aquaculture and Fisheries Group, Wageningen University, PO Box 338, 6700 AH Wageningen,

The Netherlands. E-mail: Leo.nagelkerke@wur.nl 
Hecky et al., 2010). However, despite ongoing nutrient load into the lake, phytoplankton biomass has not increased since the 1990s (Silsbe et al., 2006; Sitoki et al., 2010) and is now supposedly light-limited in Lake Victoria in both shallow and deep water (Mugidde, 1993; Silsbe et al., 2006; Cózar et al., 2012). In shallow parts of Lake Victoria, light becomes limited through self-shading when phytoplankton biomass is high and in deep water when the mixed depth is greater than the euphotic depth (Hecky, 1993; Guildford et al., 2003; Mugidde et al., 2003; Gikuma-Njuru \& Hecky, 2005). Light limitation in shallow water may also be caused by resuspension of detritus and sediment and high concentrations of dissolved organic matter (Gikuma-Njuru \& Hecky, 2005; Loiselle et al., 2008). In inshore areas and bays, this organic matter originates mostly from allochthonous sources such as wastewater or run-off from cultivated shorelines whereas, in offshore areas, it originates mostly from decaying plankton (Machiwa, 2010).

When light conditions are good, nitrogen may become limiting in shallow parts of the lake (Guildford et al., 2003), while in deep water nitrogen might become limited under anoxic conditions, stimulating denitrification, which usually occurs in stratified conditions during the rainy seasons (Guildford et al., 2000; North et al., 2008). In turn, nitrogen limitation favours nitrogen-fixing cyanobacteria (Guildford et al., 2003), which now dominate the phytoplankton of Lake Victoria and are responsible for most of the nitrogen load into the lake (Kling et al., 2001; Mugidde et al., 2003). Phosphorus, on the other hand, has increased since the 1960s and is mostly in excess both in shallow and in deep parts of the lake (Hecky, 1993; Mugidde, 2001).

In contrast to the clear bottom-up effects of nutrient loading, no top-down regulation of phytoplankton biomass has been shown in in situ experiments, in which micro-crustacean grazing in shallow and deeper parts of lake Victoria apparently had little effect on chlorophyll $a$ concentrations (Lehman \& Branstrator, 1993). Moreover, the relative abundance of large-bodied grazers was very low and omnivorous cyclopoid copepods dominated the zooplankton of the Mwanza Gulf throughout the year (personal observations) and the rest of the lake (Mwebaza-Ndawula, 1994; Wanink et al., 2002). Therefore, we assumed that limitation of phytoplankton growth by zooplankton is minimal and was not considered in this study.

Most studies on phytoplankton dynamics and limitations have been conducted in northern Lake Victoria, in eutrophic bays with high phytoplankton biomass (Mugidde, 2001; Gikuma-Njuru \& Hecky, 2005; Silsbe et al.,
2006; Haande et al., 2011). In general, the southern part of the lake has lower seasonal peaks in phytoplankton biomass, however, and they occur 2 months later than in the northern part, possibly because of a lake-wide convective circulation of water (Cózar et al., 2012). It is unclear whether the phytoplankton dynamics in the north, and their drivers, are the same for the whole of Lake Victoria. Furthermore, phytoplankton dynamics have rarely been studied for southern Lake Victoria. The few studies conducted have focussed on large spatial scales between Gulfs or depth strata covering half the lake (Shayo, Lugomela \& Machiwa, 2011; Ngupula et al., 2012). Therefore, this study focussed on the dynamics of phytoplankton biomass and water quality on a small spatial scale in the Mwanza Gulf in southern Lake Victoria, covering a depth gradient from $3 \mathrm{~m}$ in inshore water in the south to $30 \mathrm{~m}$ in offshore water near the entrance of the Gulf. This depth gradient makes Mwanza Gulf an excellent area to study the spatial dynamics and limitations of phytoplankton biomass in detail.

To study the dynamics of phytoplankton biomass and growth limitation, we examined spatial and seasonal dynamics of water quality parameters, light attenuation and chlorophyll $a$ concentrations in the Mwanza Gulf from shallow inshore to deep offshore water. We addressed the following questions: (i) How does phytoplankton biomass vary in time and space? and (ii) What are the factors driving this variability: is it light, nutrients or a combination of both?

\section{Methods}

\section{Study area}

Mwanza Gulf is located in the south of Lake Victoria (Tanzania) and is about $60 \mathrm{~km}$ long, $2.5-11 \mathrm{~km}$ wide and has a surface area of approximately $500 \mathrm{~km}^{2}$ (Fig. 1; Witte \& Van Densen, 1995). Its irregular shoreline is characterised by a vegetation of papyrus (Cyperus papyrus), reeds (e.g. Phragmites australis) and water hyacinth (Eichhornia crassipes), alternating with rock formations. The bottom consists of soft mud. The catchment area of the Mwanza Gulf is used mainly for agriculture (ranging from $62.9 \%$ in the north to $71.8 \%$ in the south). Bush land, formerly used for agriculture, covers around $20 \%$ of the catchment area. In the south $5.1 \%$ consists of natural habitats such as swamps and woodland, whereas this is only $0.7 \%$ in the north. Here, urban area covers $16.2 \%$ (Mwanza City; Fig. 1). Forests are absent around Mwanza Gulf (Vlieghe, 2000). 


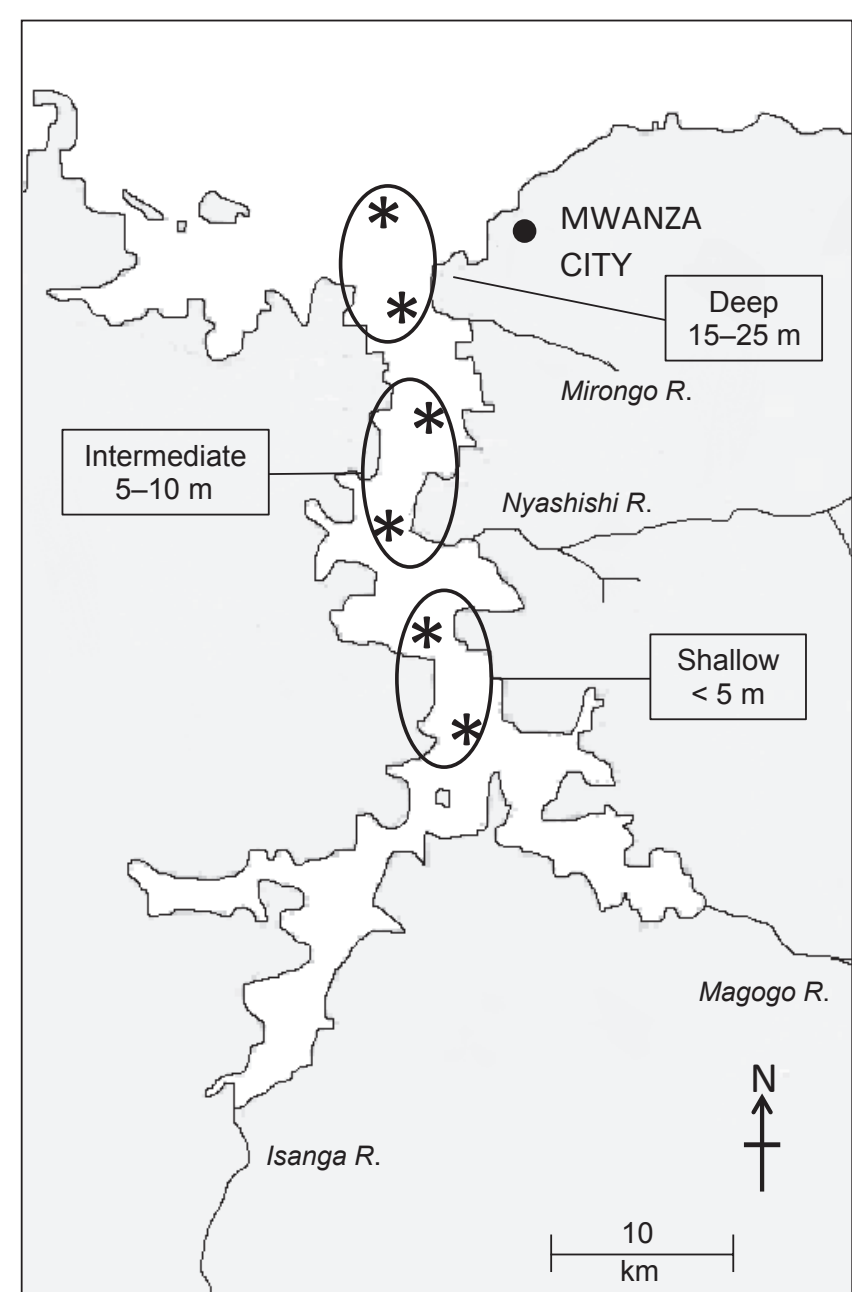

Fig. 1 Map of the Mwanza Gulf with six sampling stations (asterisks). Stations were divided in three areas to facilitate data analyses: (1) shallow $=$ depth range of $<5 \mathrm{~m}$, (2) intermediate $=$ depth range of 5-10 $\mathrm{m}$ and (3) deep = depth range of 15-25 $\mathrm{m}$.

Whereas most of the water flowing into the Gulf comes from surface run-off, forming seasonal streams during the rainy season, there are also some permanent rivers (Fig. 1). The Isanga River in the south is the largest with a mean annual discharge of $29.8 \mathrm{~m}^{3} \mathrm{~s}^{-1}$ and a catchment area of $6812 \mathrm{~km}^{2}$. The Magogo River has a mean discharge of $8.9 \mathrm{~m}^{3} \mathrm{~s}^{-1}$ and a catchment area of $5207 \mathrm{~km}^{2}$ (Myanza et al., 2005). These rivers collect waste water from fish processing plants and a brewery. Towards the north, the Nyashishi River with a mean annual discharge of $1.7 \mathrm{~m}^{3} \mathrm{~s}^{-1}$ and a catchment area of $1565 \mathrm{~km}^{2}$ flows into the gulf and in Mwanza city in the north, a small river (the Mirongo) collects waste water from the city and industrial plants before flowing into the lake. Compared to other gulfs in the lake, Mwanza Gulf has weak river input and is poorly flushed (Machiwa, 2010).

\section{Climate}

There are three seasons in Lake Victoria based on the yearly monsoon cycles. There is a dry season from June to August, when water temperature is low and strong southerly winds keep the water column well mixed, oxygenated and isothermal (Talling, 1966; Akiyama, Kajumulo \& Olsen, 1977). In the short rains, from September to December, the water column gradually stratifies as the wind declines, rainfall increases and the surface layer of the water column warms up. During the long rains, from January to May, precipitation is high and stratification is strongest (Talling, 1966). However, both the onset and the timing of rainfall in the Lake Victoria basin are highly variable (Kizza et al., 2009).

Mwanza Gulf had similar seasons during the sampling period from 2009 to 2011, although during the short and long rains, from September 2009 to May 2010, rainfall was twice as much as from September 2010 to May 2011.

\section{Data collection}

Data were collected from August 2009 until April 2011 at six sampling stations along a north-south gradient in three areas (Fig. 1). Data from the six stations were pooled for analyses into three areas: shallow $(<5 \mathrm{~m}$ depth), intermediate (5-10 $\mathrm{m}$ depth) and deep water (10-25 m depth; Fig. 1). In 2009-2010, sampling at all stations was done once per season, starting in August 2009 during the dry season and ending in May 2010 during the long rains. In 2010-2011, sampling was done three times per season, starting in June 2010 during the dry season and ending in April 2011 during the long rains. At each station, three locations, separated ca. $500 \mathrm{~m}$ from each other, were sampled between 10:00 h and 14:00 h. To minimise direct littoral influences, sampling at each station was done at least $1.5 \mathrm{~km}$ from the shore. In May 2012, additional observations were carried out on dissolved organic matter fractions.

A hydrolab DS5 multiprobe (OTT Messtechnik GmbH \& Co, Kempten, Germany) collected vertical profiles of temperature, conductivity and chlorophyll $a$ from the bottom to the surface. A mounted spherical quantum sensor (LI-COR Biosciences, Lincoln, Nebraska, U.S.A.) measured photosynthetic active radiation. Water samples were taken on three occasions throughout the sampling period for calibration. Conductivity was calibrated by using standards with known conductivity and chlorophyll $a$ by using extraction in $80 \%$ ethanol at $75{ }^{\circ} \mathrm{C}$ for 5 min (Moed \& Hallegraef, 1978). Probe measurements 
were in general 1.5- to 2-fold lower compared to the extracted chlorophyll $a$ analyses. Chlorophyll $a$ measurements with the probe were corrected with the extracted calibration analyses of chlorophyll $a$.

At each station, Secchi depth was measured in triplicate with a $25-\mathrm{cm}$-diameter black and white Secchi disc and was defined as the average depth at which the disc disappeared when lowering it in the water and reappeared when lifting it.

At each sampling station, water samples were taken every metre over the euphotic depth by using a Van Dorn water sampler. Samples were pooled for analyses of the following nutrients: total phosphorus (TP), total nitrogen $(\mathrm{TN})$; particulate fractions: particulate organic carbon (POC) and particulate inorganic matter (PIM); and dissolved fractions: dissolved organic carbon (DOC), chromophoric dissolved organic matter (CDOM) and humic acid. Nutrients were analysed in the laboratory by a digestion and photometric method (Merck KGaA, Darmstadt, Germany). Water was filtered through a glass-fibre $\mathrm{C}$ filter (Whatman $\mathrm{GmbH}$, Den Bosch, the Netherlands), and seston was used for analyses of POC and PIM. Particulate organic carbon was analysed with the standard loss on ignition method (American Public Health Association (APHA), 2005), whereby the organic fraction was calculated by the seston mass combusted for $1 \mathrm{~h}$ at $550{ }^{\circ} \mathrm{C}$ subtracted from the mass dried at $105^{\circ}$ for $24 \mathrm{~h}$ and divided by 2.5 to get the carbon content. Particulate organic carbon contains carbon derived from mainly phytoplankton and detritus. Detritus was calculated by estimating the carbon content of chlorophyll by using a chlorophyll: dry mass ratio of $1: 50$ (Bailey-Watts, 1974) and a dry mass: carbon ratio of $2: 1$ (Winberg, 1971). This calculated C concentration was subtracted from POC to estimate the carbon concentrations of detritus. For estimating PIM, five unused filters were weighed after combustion at $550{ }^{\circ} \mathrm{C}$ for $1 \mathrm{~h}$, and the average mass was subtracted from that of the filters with seston after combustion.

Water for DOC, CDOM and HA was filtered through $0.22 \mu \mathrm{m}$ pore filter and the filtrate collected for analyses. Dissolved organic carbon was analysed by chemical oxygen demand (American Public Health Association; APHA, 2005). Chromophoric dissolved organic matter and HA were determined by measuring the absorbance at 272 and $465 \mathrm{~nm}$ and calibrated gravimetrically (Mazzuoli et al., 2003).

Pooled water samples from the euphotic zone were preserved in glutaraldehyde and sent to the Netherlands Institute of Ecology for analyses with a phyto-PAM fluorometer (Walz, Germany) to differentiate between chlo- rophytes, diatoms and cyanobacteria. On 1 September 2010 and 4 April 2011, water samples from station 1, 3 and 6 were preserved with lugol, and after sedimentation, phytoplankton was generally classified to the genus or species and abundances estimated. Phytoplankton was counted as number of colonies, but the number of cells per colony was noted and all colonies were classified into size classes.

\section{Estimating physical parameters}

Water density was calculated using vertical profiles of temperature and conductivity (Chen \& Millero, 1977). Thermal stability of the water column $\left(N^{2}\right)$ was calculated according to the following equation (Langenberg, 2008):

$$
N^{2}=\frac{-g \Delta \rho}{\bar{\rho} \Delta z}
$$

where $N$ is the Brunt-Vaisälä buoyancy frequency, $g$ is the gravitational acceleration $\left(\mathrm{m} \mathrm{s}^{-2}\right),(\Delta \rho / \Delta z)$ is the density gradient over a depth interval and $\bar{\rho}$ is the mean density over the water column $\left(\mathrm{kg} \mathrm{L}^{-1}\right)$.

Water temperature $\left(T_{\text {water }}\right)$ was defined as the mean temperature over the whole water column. Mixed depth $\left(Z_{\text {mix }}\right)$ was defined as the maximum change in temperature with depth over the water column. The euphotic depth $\left(Z_{\text {euph }}\right)$ was defined as the depth at which $1 \%$ of the surface irradiance remains.

\section{Analysis of spatial and seasonal dynamics}

The spatial and seasonal effects on the dynamics of stratification, water quality and light-associated parameters and phytoplankton data were analysed by KruskalWallis tests because normality could not be achieved directly or after $\log$ transformations. In case of significant spatial or seasonal effects, post hoc pairwise comparisons were performed with adjusted levels for multiple comparisons using a Bonferroni correction.

\section{Analyses of light conditions}

The attenuation of photosynthetically active radiation (PAR: $400-700 \mathrm{~nm}$ wave length) is caused by optically active components in the water column and expressed by the attenuation coefficient $K_{\text {PAR }}$. $K_{\text {PAR }}$ was estimated as the slope of the linear regression of the natural logarithm of PAR on depth of each vertical profile. Regression correlation coefficients of $<0.9$ and regressions with $<15$ observations within a single vertical profile, were 
excluded from further data analyses. In fresh water, light attenuating components consist mainly of phytoplankton biomass and background attenuation of other components such as coloured CDOM, inorganic sediments, suspended detritus and pure water (Morel, 1988):

$$
K_{\mathrm{PAR}}=\left(k_{\mathrm{Chl}} \cdot \mathrm{Chl}\right)+K_{\mathrm{bg}}
$$

where $k_{\mathrm{Chl}}$ is the specific light attenuation coefficient for phytoplankton $\left(\mathrm{m}^{2} \mathrm{mg}^{-1}\right)$ determined by the slope of linear regression of $K_{\mathrm{PAR}}\left(\mathrm{m}^{-1}\right)$ on chlorophyll $a$ concentration in the euphotic zone ( $\mathrm{Chl}$, in $\left.\mathrm{mg} \mathrm{m}^{-3}\right) . K_{\mathrm{bg}}$ is the background attenuation $\left(\mathrm{m}^{-1}\right)$, determined as the intercept with the $K_{\mathrm{PAR}}$ axis of the same linear regression. To analyse the relationship between chlorophyll concentrations and $K_{\mathrm{PAR}}$, we performed regression analyses of $K_{\text {PAR }}$ on $\mathrm{Chl}$ (with or without $\log _{\mathrm{e}}$ transformation, depending on the normality of the residuals). The residuals from these regression analyses indicate background attenuation, as the influence of chlorophyll $a$ is excluded. These residuals were used to determine the influence of suspended detritus on $K_{\mathrm{PAR}}$, by correlating them with suspended detritus concentrations $\left(C_{\text {detritus }}\right)$. As these residuals were not normally distributed, a nonparametric Spearman's rank correlation was used. Similarly, $K_{\text {PAR }}$ and PIM were also correlated with a Spearman's rank correlation. Next, to test whether the relationship between $K_{\mathrm{PAR}}$ and chlorophyll a concentrations differed between areas, we also performed an analysis of covariance of $K_{\mathrm{PAR}}$, with area as factor and $\mathrm{Chl}$ as covariate.

Solar irradiance was integrated over the mixed depth to determine the total integrated irradiance in the mixed layer by the following equation (Loiselle et al., 2007):

$$
Q_{t}=I_{0} /\left(k_{\mathrm{Chl}} \cdot \mathrm{Chl}+K_{\mathrm{bg}}\right) \cdot\left(1-e^{-\left(k_{\mathrm{Chl}} \cdot \mathrm{Chl}+K_{\mathrm{bg}}\right) Z_{\mathrm{mix}}}\right)
$$

where $Q_{t}$ is the total integrated irradiance in the mixed layer (mol photon $\mathrm{m}^{-2}$ day $^{-1} \mathrm{~m}$ ) and $I_{0}$ is the incident irradiance just below the water surface.

\section{Estimating maximum phytoplankton biomass under light limitation}

We used a light limitation approach based on the carrying capacity of phytoplankton biomass developed by Loiselle et al. (2007, 2008). This approach uses the calculated available irradiance $\left(Q_{t}\right)$ and the chlorophyll $a$ biomass per unit area $\left(\mathrm{mg} \mathrm{m}^{-2}\right)$ to determine where light limitation occurs. Chlorophyll $a$ biomass per unit area can be calculated when Chl concentration in $\mathrm{mg} \mathrm{m}^{-3}$ is multiplied with $Z_{\text {mix }}$. When $Q_{t}$ is plotted against chlorophyll $a$ biomass per unit area, a linear regression of 10 data points with highest chlorophyll $a$ over the $Q_{t}$ range

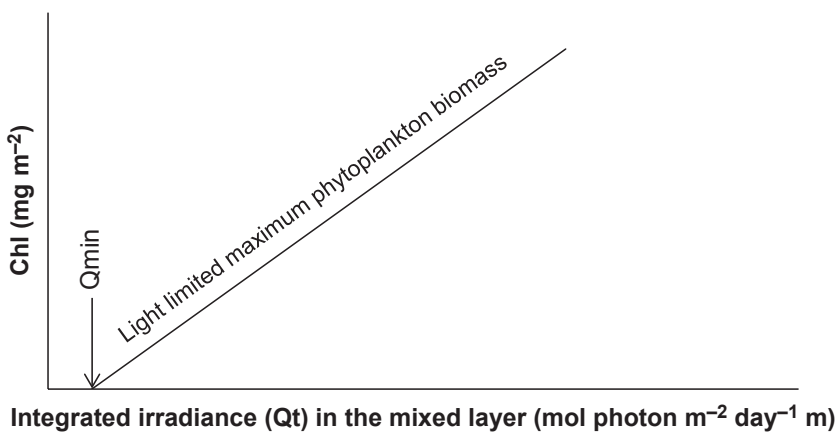

Fig. 2 The relationship between daily depth integrated light irradiance and phytoplankton biomass per unit area ( $\mathrm{mg} \mathrm{Chl} a \mathrm{~m}^{-2}$ ) under light-limited conditions over the mixed layer. The line represents the maximum potential chlorophyll $a$ concentrations when light is limited (upper limit), determined by regression of 10 sites with highest chlorophyll $a$ concentrations. The intercept represents minimum light requirement $\left(\mathrm{Q}_{\min }\right)$ for phytoplankton growth and the slope is the expected maximum phytoplankton biomass under light limitation.

defines the carrying capacity for phytoplankton biomass under light limitation in a steady state (Fig. 2). The minimum irradiance to allow phytoplankton biomass is the intercept with the $Q_{t}$ axis, and the critical light requirement is the slope of the same linear regression. From this, we calculated the expected chlorophyll $a$ biomass per unit area under light limitation:

$$
W=Q_{t}-Q_{\min } / \psi
$$

where $W$ is the expected depth integrated chlorophyll $a$ biomass per unit area $\left(\mathrm{mg} \mathrm{m}^{-2}\right), Q_{\min }$ is the minimal light requirement for allowing phytoplankton biomass (mol photon $\mathrm{m}^{-2}$ day $^{-1} \mathrm{~m}$ ) and $\psi$ is the critical light requirement $\left[\mathrm{mol}\right.$ photon $\mathrm{m}^{-1}$ day $^{-1}\left(\mathrm{mg} \mathrm{m}^{-2}\right.$ chlorophyll $a)^{-1}$.

By comparing the measured chlorophyll $a\left(\mathrm{mg} \mathrm{m}^{-2}\right)$ with the expected light-limited maximum chlorophyll $a$ $(W)$, the relative degree of limitation by light and/or other factors was determined. Measured chlorophyll $a$ located further from the expected $W$ is probably limited by factors such as nutrients, so we calculated the distance between measured chlorophyll $a$ and $W$. The latter $(W)$ is calculated by using a combination of eqns 2,3 and 4 for each measured chlorophyll $a$ concentration. Note that the distance between measured chlorophyll $a$ and $W$ increases exponentially by using eqn 3 , because phytoplankton biomass cannot increase linearly with light, as phytoplankton itself will have a negative feedback on irradiance when increasing in biomass (Loiselle et al., 2007, 2008). The distance is then plotted against $P$, $\mathrm{N}$ and detritus concentrations, and correlations are tested with Pearson's or Spearman's rank, according to 
normality of the data, to investigate the potential role of nutrients and detritus dynamics in determining phytoplankton biomass. With increasing distance, chlorophyll is less likely to be limited by light and must be limited by another factor. A negative correlation between distance and nutrients or detritus suggests that nutrients or detritus might become limited when light conditions are good. A positive or no correlation might indicate a limitation by other factors not measured in this study.

\section{Results}

Spatial and seasonal dynamics

Variables associated with stratification and water column stability, such as $T_{\text {water }}$ and $N^{2}$, differed between seasons but not between areas (Table 1). Highest temperatures and stability occurred during the short rains
(September-December; Table 1). Water column mixing was deepest during the dry season (June-August) and shallow during the short and long rains. This seasonal trend in mixing and temperature was observed in both shallow as well as deeper parts of the Gulf (Fig. 3).

Spatial and seasonal effects differed among water quality variables (Table 1). Total phosphorus concentration varied seasonally with a slightly higher concentration during the short rains (September-December) than the long rains (January-May). Total nitrogen concentration and TN : TP molar ratio showed a strong spatial pattern with decreasing values from shallow to deep water. TN also varied seasonally, with highest concentrations during the dry season and short rains and lowest during the long rains. From the particulate fractions, POC varied spatially with highest concentrations in shallow water and lowest concentrations in deep water and seasonally with highest concentrations

Table 1 Summary table of means with post hoc pairwise comparisons and results of the Kruskal-Wallis tests of effects of area (shallow, intermediate and deep water) and season (dry period, short and long rains) on physical conditions, light-associated parameters, nutrients and phytoplankton

\begin{tabular}{|c|c|c|c|c|c|c|c|c|c|c|}
\hline & \multicolumn{3}{|l|}{ Area } & \multicolumn{3}{|l|}{ Season } & \multicolumn{2}{|l|}{ Area } & \multicolumn{2}{|l|}{ Season } \\
\hline & $\begin{array}{l}\text { Shallow } \\
(<5 \mathrm{~m})\end{array}$ & $\begin{array}{l}\text { Intermediate } \\
(5-10 \mathrm{~m})\end{array}$ & $\begin{array}{l}\text { Deep } \\
(15-25 \mathrm{~m})\end{array}$ & Dry & $\begin{array}{l}\text { Long } \\
\text { rains }\end{array}$ & $\begin{array}{l}\text { Short } \\
\text { rains }\end{array}$ & $H$ & $P$ & $H$ & $P$ \\
\hline \multicolumn{11}{|l|}{ Stratification } \\
\hline$T_{\text {water }}\left({ }^{\circ} \mathrm{C}\right)$ & 24.75 & 24.98 & 24.94 & $23.92^{\mathrm{a}}$ & $24.98^{\mathrm{b}}$ & $25.74^{\mathrm{b}}$ & 2.19 & NS & 131.10 & $<0.001$ \\
\hline$N^{2}\left(10^{-3}\right)$ & 0.49 & 0.36 & 0.39 & $0.25^{\mathrm{a}}$ & $0.42^{\mathrm{ab}}$ & $0.56^{\mathrm{b}}$ & 2.29 & NS & 18.92 & $<0.001$ \\
\hline \multicolumn{11}{|c|}{ Water quality parameters $\left(\mathrm{mg} \mathrm{L}^{-1}\right)$} \\
\hline $\mathrm{TN}$ & $1.42^{\mathrm{C}}$ & $0.89^{\mathrm{b}}$ & $0.48^{\mathrm{a}}$ & $1.06^{\mathrm{b}}$ & $0.80^{\mathrm{a}}$ & $0.92^{\mathrm{b}}$ & 105.32 & $<0.001$ & 8.65 & 0.013 \\
\hline $\mathrm{TP}$ & 0.08 & 0.08 & 0.07 & - & $0.07^{\mathrm{a}}$ & $0.09^{\mathrm{b}}$ & 2.23 & NS & 24.88 & $<0.001$ \\
\hline $\mathrm{TN}$ : TP molar & $45.92^{\mathrm{c}}$ & $25.96^{\mathrm{b}}$ & $11.81^{\mathrm{a}}$ & - & 31.66 & 20.77 & 56.07 & $<0.001$ & 1.21 & NS \\
\hline PIM & 17.66 & 30.71 & 86.22 & $13.81^{\mathrm{a}}$ & $79.95^{\mathrm{b}}$ & $43.56^{\mathrm{a}}$ & 4.44 & NS & 14.48 & $<0.001$ \\
\hline \multicolumn{11}{|c|}{ Light-associated parameters } \\
\hline$Z_{\text {euph }}(\mathrm{m})$ & $2.77^{\mathrm{a}}$ & $3.52^{\mathrm{b}}$ & $5.57^{\mathrm{c}}$ & $4.83^{\mathrm{c}}$ & $3.38^{\mathrm{a}}$ & $3.62^{\mathrm{b}}$ & 91.02 & $<0.001$ & 28.62 & $<0.001$ \\
\hline Secchi depth (m) & $0.63^{\mathrm{a}}$ & $1.08^{\mathrm{b}}$ & $1.91^{\mathrm{c}}$ & $1.42^{\mathrm{c}}$ & $1.10^{\mathrm{b}}$ & $1.07^{\mathrm{a}}$ & 142.20 & $<0.001$ & 17.17 & $<0.001$ \\
\hline$K_{\mathrm{PAR}}\left(\mathrm{m}^{-1}\right)$ & $2.52^{\mathrm{a}}$ & $1.87^{\mathrm{b}}$ & $1.04^{c}$ & $1.37^{\mathrm{a}}$ & $2.05^{c}$ & $2.01^{\mathrm{b}}$ & 82.70 & $<0.001$ & 17.73 & $<0.001$ \\
\hline \multicolumn{11}{|c|}{ Phytoplankton $\left(\mu \mathrm{g} \mathrm{L}^{-1}\right)$} \\
\hline Chlorophyll $a$ & $17.06^{\mathrm{c}}$ & $15.32^{\mathrm{b}}$ & $9.25^{\mathrm{a}}$ & 13.24 & 14.96 & 13.45 & 85.46 & $<0.001$ & 0.472 & NS \\
\hline Cyanobacteria & $3.55^{\mathrm{c}}$ & $3.21^{\mathrm{b}}$ & $0.96^{\mathrm{a}}$ & $1.48^{\mathrm{a}}$ & $2.01^{\mathrm{a}}$ & $4.18^{\mathrm{b}}$ & 53.42 & $<0.001$ & 31.81 & $<0.001$ \\
\hline Chlorophytes & 0.09 & 0.00 & 0.00 & 0.03 & 0.02 & 0.04 & 6.02 & NS & 0.004 & NS \\
\hline Diatoms & $1.02^{\mathrm{b}}$ & $1.17^{\mathrm{b}}$ & $0.67^{\mathrm{a}}$ & $0.76^{\mathrm{a}}$ & $0.80^{\mathrm{a}}$ & $1.29^{\mathrm{b}}$ & 30.19 & $<0.001$ & 39.66 & $<0.001$ \\
\hline
\end{tabular}

Significance levels were corrected according to Bonferroni with $\mathrm{df}=2$ except for seasonal effect on TP and TN : TP in which significance level was at $P<0.05$ with $\mathrm{df}=1$. Mean values with different superscripts differ significantly.

$H$, test statistic Kruskal-Wallis; NS, not significant; $P$, significance level; $T_{\text {water, }}$ water column temperature; $N^{2}$, buoyancy frequency; $Z_{\text {max }}$ maximum depth; $Z_{\text {mix }}$, mixed depth; $Z_{\text {euph, }}$ euphotic depth; $K_{\mathrm{PAR}}$, light attenuation coefficient; $\mathrm{TN}$, total nitrogen; TP, total phosphorus; POC, particulate organic carbon; PIM, particulate inorganic matter; DOC, dissolved organic carbon; CDOM, chromophoric dissolved organic matter; HA, humic acid; DOC, CDOM and HA were sampled in May 2012. 

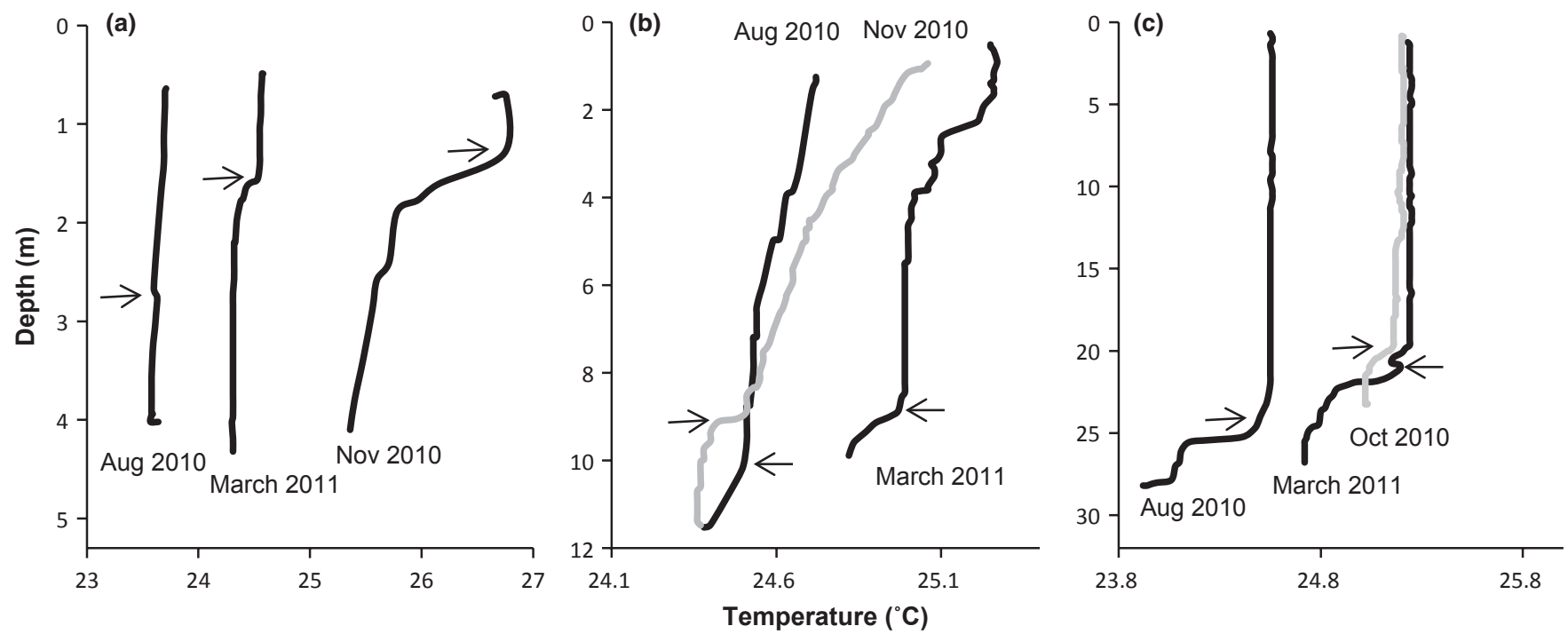

Fig. 3 Temperature-depth profiles at three sampling stations of contrasting depths on one occasion each season in the Mwanza Gulf. (a) At the most southern and shallow sampling station of 4-5 m depth, measurements were taken at 11:21, 10:15 and 11:58 h, respectively, (b) at an sampling station of intermediate depth (10-12 m depth), measurements were taken at 11:31, 10:42 and 13:37 h, respectively, and (c) at the most northern and deep station of 25-30 m depth, measurements were taken at 9:13, 10:46 and 10:44 h, respectively. Arrows indicate the mixing depths.

during the long rains. Particulate inorganic matter was seasonally affected and showed the highest concentration during the long rains. From the dissolved organic matter fractions, both DOC and CDOM varied spatially. Dissolved organic carbon concentration was lowest in deep water, whereas CDOM was highest in shallow water and lowest in deep water. Humic acid (HA) concentrations were very low and did not vary between areas.

Chlorophyll $a$ concentrations varied from shallow to deep water and to a lesser extent between seasons (Table 1). Total chlorophyll $a$ concentration, as well as chlorophyll concentrations of the main taxonomic phytoplankton groups, all decreased with depth. Cyanobacteria and diatoms also varied seasonally, with highest concentrations during the short rains, whereas chlorophytes occurred only at very low concentrations in all areas and seasons. Phytoplankton density in September 2010 and April 2011 (stations 1, 3 and 6) showed very low abundances of $\mathrm{N}$-fixing phytoplankton species $(<4.5 \%$ of total abundance). N-fixing species found in September 2010 were Anabaena spp. and Cylindrospermopsis africana; in April 2011 Anabaena spp., Cylindrospermopsis africana, C. cuspus, C. philippinensis, C. raciborskii and C. helicoida. On both occasions close to the date of phytoplankton sampling, $\mathrm{N}: \mathrm{P}$ ratio was highest in shallow water (36.4 on 26 August 2010 and 71.1 on 1 April 2011) and lowest in deep water (24.5 on 27 August 2010 and 19.1 on 31 March 2011).
Light-associated parameters were all affected spatially and seasonally (Table 1). The light attenuation coefficient $\left(K_{\text {PAR }}\right)$ decreased from shallow to deep water, following the chlorophyll $a$ trend. Highest $K_{\mathrm{PAR}}$ values occurred during the long rains, although seasonal differences were less conspicuous than spatial differences. Euphotic zone depth and Secchi depth showed similar spatial trends with greatest values in deep water and during the dry season.

\section{Light conditions in Mwanza Gulf}

A power regression model best described the relationship between $K_{\mathrm{PAR}}$ and chlorophyll a concentration $\left(K_{\text {PAR }}=0.27 \cdot \mathrm{Chl}^{0.71}, \quad R^{2}=0.47, \quad F=67.94, \quad P<0.0001\right.$, $n=80$ : Fig. $4 a)$. However, the high values of $K_{\mathrm{PAR}}$ and extent of the variation around the relationship suggested that background light attenuation $\left(K_{\mathrm{bg}}\right)$ was high and varied between areas (Fig. 4a). When using ANCOVA, with area as factor and chlorophyll $a$ concentration as covariate, we indeed found a strong influence of both chlorophyll and area on $K_{\mathrm{PAR}}\left(R^{2}=0.69, \quad F=55.03\right.$, $P<0.0001, n=80$ : Fig. $4 b)$. There was no interaction between chlorophyll and area $(F=0.78, P=0.46, n=80)$, and the decreasing intercept from shallow to deep water indicates a decreasing influence of background light attenuation $\left(K_{\mathrm{bg}}\right)$ from shallow to deep water on $K_{\text {PAR }}$ (Fig. $4 \mathrm{~b}$ ). The specific attenuation coefficient for chlorophyll $a\left(k_{\mathrm{chl}}\right)$ was $0.0357\left(\mu \mathrm{g} \mathrm{L}^{-1}\right) \mathrm{m}^{-1}$ (95\% CL $\left.=0.016-0.055\right)$. 
134 I. J. M. Cornelissen et al.
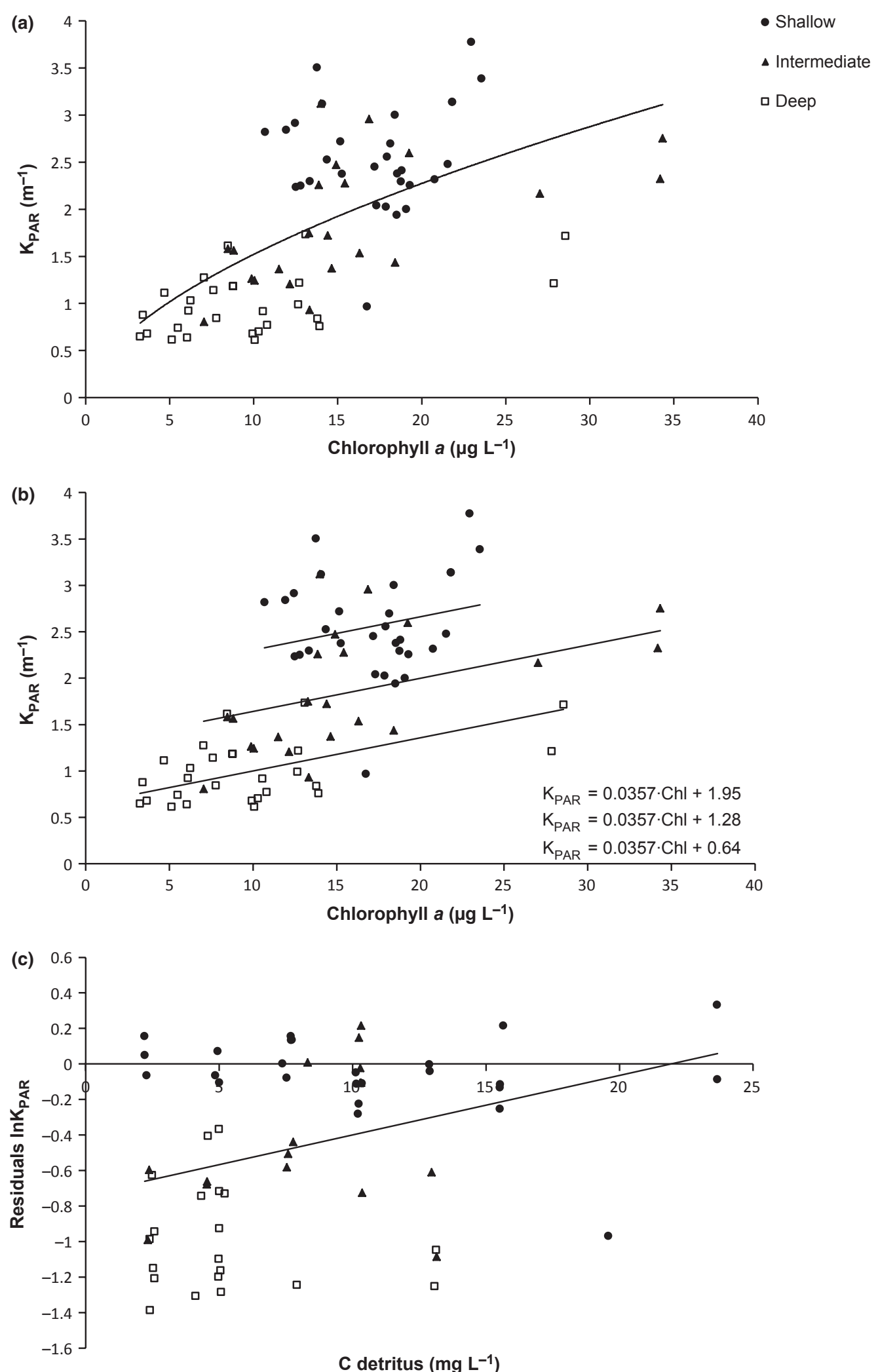

Fig. 4 The relationship between chlorophyll $a$ concentration and the light attenuation coefficient $\left(K_{\mathrm{PAR}}\right)$ in the Mwanza Gulf: (a) power regression of chlorophyll $a$ concentrations versus $K_{\mathrm{PAR}}$ in Mwanza Gulf $\left(\mathrm{R}^{2}=0.47, n=80, P<0.0001\right)$, (b) linear regression of chlorophyll $a$ versus $K_{\mathrm{PAR}}$ in Mwanza Gulf and (c) regression of detritus concentrations (mg C L ${ }^{-1}$ ) versus residuals of $\ln K_{\mathrm{PAR}}\left(\mathrm{R}^{2}=0.12, n=61\right.$, $P=0.007)$. 
A high $K_{\mathrm{bg}}$ in shallow water can be caused, among other factors, by suspended detritus. There was a significant positive correlation between the suspended detritus concentration $\left(C_{\text {detritus }}\right)$ with the residuals of $K_{\text {PAR }}$ from the power regression $\left(r_{\mathrm{s}}=0.27, P=0.03\right)$, suggesting that detritus played a significant role in explaining the differences in light attenuation in Mwanza Gulf. However, in the regression, only $12 \%$ of the variance of residuals was explained (Fig. 4c), indicating that, in addition to chlorophyll and detritus, other light absorbers like PIM or CDOM could have contributed to light attenuation in the Mwanza Gulf. Particulate inorganic matter was not significantly correlated with $K_{\mathrm{PAR}}(P=0.33)$ and, because of the limited data on the dissolved fractions, we could not directly test the influence of CDOM or DOC on $K_{\text {PAR. }}$.

\section{Limitation on phytoplankton biomass}

Shallow and intermediate water was more light-limited than deep water, and data points were in general located closer to the upper limit of chlorophyll $a$ concentrations per unit area under light limitation (Fig. 5). The minimum light requirement to allow phytoplankton biomass was $9.01 \mathrm{~mol}$ photon $\mathrm{m}^{-2}$ day $^{-1} \mathrm{~m}$. The critical light requirement was $0.064 \mathrm{~mol}$ photon $\mathrm{m}^{-1}$ day $^{-1}$ $\left(\mathrm{mg} \mathrm{m}^{-2} \text { chlorophyll } a\right)^{-1}$.

The calculated distance to the upper limit of chlorophyll $a$ was plotted against nutrients and detritus (Fig. 6). A Spearman's rank test showed a significant negative correlation of $\mathrm{TN}$ concentrations with distance from the upper limit $\left(r_{s}=-0.24, P=0.04\right)$. A negative correlation of detritus with distance was found $\left(r_{s}=-0.21, P=0.04\right)$. Correlation between TP concentrations and distance was very weak and not significant $\left(r_{s}=-0.08, P=0.61\right)$.

\section{Discussion}

\section{Spatial and seasonal dynamics}

Stratification in the Mwanza Gulf varied among seasons, but the differences in mean mixed depth were not more than $2 \mathrm{~m}$ between seasons. This relatively weak effect of season suggests that stratification was not persistent throughout the rainy seasons. Lake Victoria has distinct diurnal rainfall and air convection patterns (Nicholson \& Yin, 2002), which can build up and breakdown stratification on a daily basis. In the Mwanza Gulf, the water was mostly calm in the morning, but winds picked up in the afternoons (I. Cornelissen, pers. observ.), probably causing a breakdown of the stratification built up the previous night. This diurnal break-up of the stratification was also observed in inshore waters of $15 \mathrm{~m}$ in Uganda (Macintyre, Romero \& Kling, 2002).

The TN and phosphorus concentrations observed here were within the range reported by other authors for Lake Victoria at similar depths (TP: $0.03-0.15$ and TN: 0.5-1.5 mg L L ${ }^{-1}$; Mugidde, 2001; Gikuma-Njuru, 2008; Haande et al., 2011; Ngupula, Mbonde \& Ezekiel, 2011). Total phosphorus did not show a spatial trend, which also corresponds to other studies (Hecky, 1993; Mugidde, 1993). More than half of the P loading into the lake originates from atmospheric wet and dry deposition. Run-off is only of local importance (Tamatamah et al., 2005). Total nitrogen concentrations were about threefold higher in shallow than in deep water, resulting in higher TN : TP ratios in shallow water, corresponding to other studies in Lake Victoria (Mugidde, 2001; Gikuma-Njuru \& Hecky, 2005).

In deep water, PIM probably originated from wastewater from Mwanza City and from river discharges and
Fig. 5 Chlorophyll $a$ concentration per unit area and integrated light irradiance over the mixed layer in the Mwanza Gulf. The line represents the maximum potential chlorophyll $a$ concentrations when light is limited (upper limit), determined by regression of 10 sites with highest chlorophyll $a$ concentrations per unit area and lowest integrated irradiance $\left(\mathrm{R}^{2}=0.57, n=10, P=0.01\right)$. Sites close to upper limit are more lightlimited than points far from the upper limit: $n=80$.

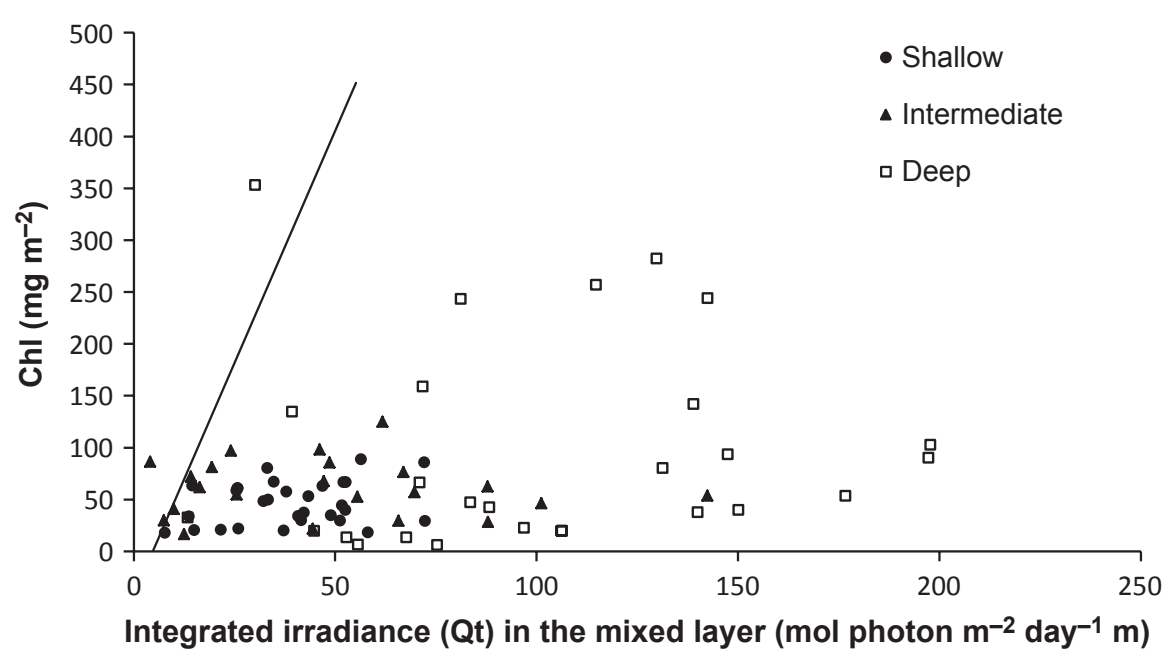

(C) 2013 John Wiley \& Sons Ltd, Freshwater Biology, 59, 127-141 
from resuspension of sediment through turbulence in shallow water (Lung'ayia et al., 2000; Machiwa, 2010). The high PIM concentrations observed during the long rainy season were probably caused by high land run-off into the lake and resuspension of sediment (Lung'ayia et al., 2000). Particulate organic carbon concentration in our study was twofold higher inshore than offshore, which corresponds with spatial trends of particulate carbon in other studies in the Mwanza Gulf and in Ugandan water (Mugidde, 2001; Hecky et al., 2010; Machiwa, 2010).
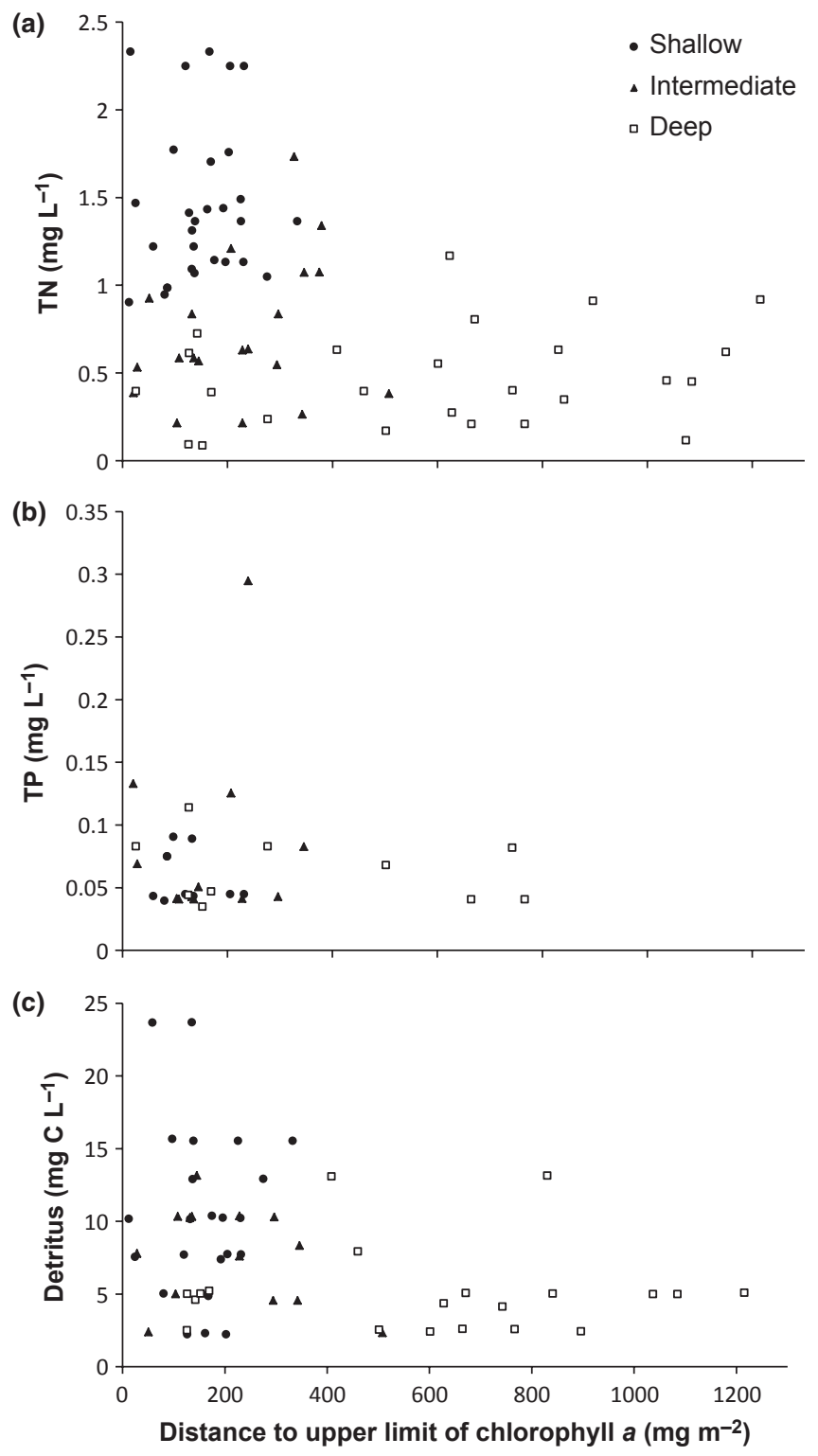

Fig. 6 Distances between measured chlorophyll $a$ concentrations and the calculated maximum concentrations under light limitation in relation to varying nutrient and detritus concentrations: (a) total nitrogen concentrations ( $\mathrm{TN} ; n=76$ ), (b) total phosphorus concentrations (TP; $n=34)$ and (c) detritus concentrations $(n=57)$.
Chlorophyll a concentrations observed in the Mwanza Gulf fell in the same range as those measured by Shayo et al. (2011) in Mwanza Gulf and by Ngupula et al. (2012) in Tanzanian waters, but were in general two- to threefold lower than in highly eutrophic gulfs in Uganda, such as Napoleon and Murchison Gulf (Lehman \& Branstrator, 1994; Mugidde, 2001; Yasindi \& Taylor, 2003; Silsbe et al., 2006; Cózar et al., 2007; North et al., 2008; Okello et al., 2010; Haande et al., 2011). The decrease in chlorophyll concentration from shallow to deep water suggests that nutrients in shallow water were in excess, enabling a high chlorophyll concentration until light became limited. Deeper mixing than the euphotic depth and possible $\mathrm{N}$ limitation resulted in lower chlorophyll concentrations in deeper water. Similar to other studies on the Ugandan side of Lake Victoria, cyanobacteria were found to be the dominant phytoplankton group in all locations and throughout the study period (Okello et al., 2010; Haande et al., 2011). The very low concentration of chlorophytes also corresponds with other studies in Mwanza Gulf and Lake Victoria (Akiyama et al., 1977; Lung'ayia et al., 2000; Kling et al., 2001; Gikuma-Njuru, 2008; Ngupula et al., 2011).

\section{Light conditions in Mwanza Gulf}

Secchi depth was less strongly related to $K_{\text {PAR }}$ in Mwanza Gulf $\left(R^{2}=0.75, n=99\right.$ : Fig. 7$)$, than in Ugandan waters $\left(R^{2}=0.90, n=112\right.$ : Fig. 7 ; Silsbe, 2004). The relationship obtained paralleled that found for Ugandan waters, but our Secchi depths were consistently $20 \mathrm{~cm}$ greater than in Uganda at identical $K_{\mathrm{PAR}}$ values. As

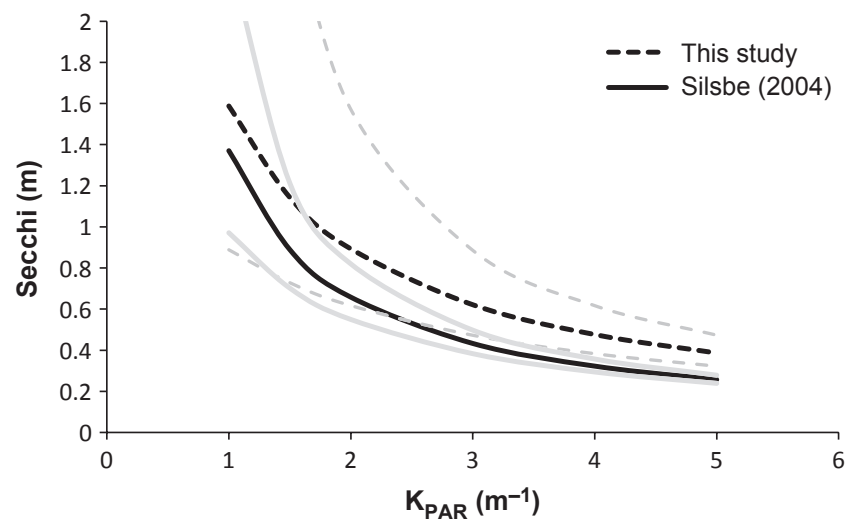

Fig. 7 Regression of $K_{\text {PAR }}$ and Secchi depth of this study in Mwanza Gulf and Silsbe (2004) in Ugandan waters. Grey dashed lines represent $95 \%$ prediction intervals of this study, and grey lines represent 95\% prediction intervals of the study of Silsbe (2004). 
$K_{\mathrm{PAR}}$ and Secchi depth measure different optical properties, that is, $K_{\mathrm{PAR}}$ measures attenuation of light in the visible wavelength range and Secchi measures clarity (Preisendorfer, 1986), $K_{\mathrm{PAR}}-$ Secchi depth relationships differ between types of water. Koenings \& Edmundson (1991) found a tenfold range of $K_{\mathrm{PAR}}-\mathrm{Secchi}$ depth relationship between different types of lakes with either stained (high in CDOM concentrations), turbid (high in concentrations of suspended particles) or clear waters. Our $K_{\mathrm{PAR}}-$ Secchi depth relationship can be classified in between clear and turbid waters. The wider $95 \%$ prediction intervals of our relationship compared with that for Uganda (Fig. 7) suggest that there is additional spatial variation in the sources of light absorption within the Mwanza Gulf.

Morel \& Prieur (1977) classified oceanic waters as 'case I' water, in which phytoplankton and detritus derived from phytoplankton contribute predominantly to the light attenuation in water, while in 'case II' water sediments and CDOM play a dominant role in light attenuation. In our study, $K_{\mathrm{PAR}}$ values were much higher in relation to the chlorophyll $a$ range than in Ugandan and Kenyan waters (Silsbe, 2004; Loiselle et al., 2008) and in oceanic case I waters (Morel, 1988), suggesting that light absorbers other than phytoplankton contributed to the light attenuation (background attenuation $K_{\mathrm{bg}}$ ) and that the Mwanza Gulf might be considered as a case II water (Fig. 8). Loiselle et al., (2008), who found a similar relationship between chlorophyll and $K_{\text {PAR }}$ as Silsbe et al., (2006), identified their study sites as case II waters. Our study showed high variation $\left(R^{2}=0.47\right)$ between $K_{\mathrm{PAR}}$ and chlorophyll $a$, suggesting

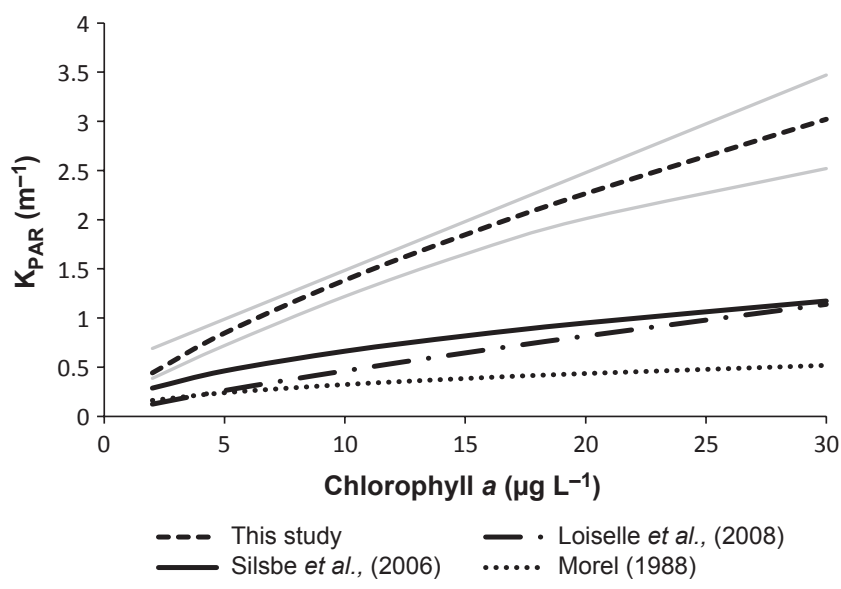

Fig. 8 Regression of chlorophyll $a$ concentrations and $K_{\text {PAR }}$ of studies in southern Lake Victoria (this study), northern Lake Victoria (Silsbe et al., 2006; Loiselle et al., 2008) and oceanic waters (Morel, 1988). Grey lines represent 95\% CL (this study). that the relative contribution of chlorophyll to light absorption varied spatially.

It becomes even more evident how strong the light attenuation by non-algal absorption in our study sites was, when we compare the integrated irradiance $\left(Q_{t}\right)$ of Morel's type I waters (which have negligible non-algal absorption), with the $Q_{t}$ in Mwanza Gulf at similar chlorophyll concentrations and surface irradiance. Our study shows that non-algal absorption removed 83,78 and $67 \%$ of the integrated irradiance in shallow, intermediate and deep water, respectively. This indicates that light limitation was caused by non-phytoplankton light absorbing properties rather than by self-shading of phytoplankton in the Mwanza Gulf.

In the Mwanza Gulf, besides phytoplankton, suspended detritus played an increasing role in PAR attenuation from deep to shallow water. In addition, shallow water had higher CDOM and DOC concentrations than deep water (Table 1), which suggests that CDOM and DOC were probably of terrestrial origin (Loiselle et al., 2007). Chromophoric dissolved organic matter concentrations were of similar magnitude as those in the Nyanza Gulf (Loiselle et al., 2007). However, as chlorophyll $a$ concentrations were much higher in the Nyanza Gulf, the relative contribution of CDOM to light attenuation could be of more importance in the Mwanza Gulf than in the Nyanza Gulf.

\section{Limitations of phytoplankton biomass}

The specific attenuation coefficient for chlorophyll $a$ $\left(k_{\mathrm{Chl}}=0.036 \mu \mathrm{g} \mathrm{L}{ }^{-1} \mathrm{~m}, 95 \% \mathrm{CL}=0.016-0.055\right)$ was considerably higher and varied more than in Ugandan and Kenyan Gulfs $\left(0.019 \pm 0.002\right.$ (SD) $\mu \mathrm{g} \mathrm{L}^{-1} \mathrm{~m}$; Loiselle et al., 2008). The specific attenuation coefficient for chlorophyll $a\left(K_{\mathrm{Chl}}\right)$ of 414 data sets of temperate freshwater and marine waters ranged from 0.004 to $0.029 \mu \mathrm{g} \mathrm{L}{ }^{-1} \mathrm{~m}$ (Krause-Jensen \& Sand-Jensen, 1998). The coefficient depends on physiological state, photo-adaptation and historical light exposure of phytoplankton and can vary considerably within and between aquatic ecosystems with different taxonomic phytoplankton communities (Dubinsky \& Berman, 1981). The high $k_{\mathrm{Chl}}$ coefficient in our study suggests that light attenuation was relatively fast at a relatively low chlorophyll $a$ biomass and that light became limited at a low chlorophyll a biomass. Furthermore, we found that the minimal and critical light requirements for phytoplankton were similar and 7.5-fold higher than in Ugandan and Kenyan gulfs, respectively (Loiselle et al., 2007). We also found that shallow and intermediate water was more light-limited 
(closer to upper limit for phytoplankton biomass) than deep water, because of higher background attenuation $\left(K_{\mathrm{bg}}\right)$ due to detritus and possibly CDOM. Although other studies confirm that, in general, phytoplankton growth in Lake Victoria is light-limited, they suggest that this is due to self-shading when phytoplankton biomass is high, especially in shallow water and during periods of stratification (Guildford et al., 2003; Gikuma-Njuru \& Hecky, 2005). In the Mwanza Gulf, where biomass was much lower than in northern Lake Victoria Gulfs, selfshading is expected to play a smaller role.

Our results suggest that factors other than light might be limiting under specific local conditions. Nitrogen was probably limited in deep water when light was not limited. This is confirmed by the TN : TP ratio of 11.8, which is lower than the ratio of $20: 1$ at which $\mathrm{N}$ generally becomes limiting for phytoplankton growth (Guildford \& Hecky, 2000). A possible cause for low N concentration might have been deoxygenation in deep water, enhancing denitrification (Hecky, 1993). The high $\mathrm{TN}$ : TP ratio of 46 in shallow water found in the present study indicates a tendency for $\mathrm{P}$ limitation besides light limitation (Guildford \& Hecky, 2000). Through $\mathrm{N}$-fixation, $\mathrm{N}$ could accumulate in the water column. Unfortunately, direct measurements of $\mathrm{N}$-fixation were not available. However, based on the very low abundances of N-fixing phytoplankton species in September 2010 and April 2011, we infer that the concurrently measured high $\mathrm{N}: \mathrm{P}$ ratios in shallow water were not caused by $\mathrm{N}$-fixation. The high nitrogen content observed in this study in the Mwanza Gulf may be better explained by inputs from run-off from cultivated and urbanised land, river discharges and internal $\mathrm{N}$ loading through low denitrification rates in well-oxygenated sediment and resuspension of sediments (Hecky, 1993; Lung'ayia, Sitoki \& Kenyanya, 2001; Présing et al., 2001). Furthermore, the slow flushing character and lack of extensive wetlands in connection with the Mwanza Gulf enable accumulation of $\mathrm{N}$. The apparent lack of $\mathrm{N}$-fixation is in contrast to other studies in Lake Victoria, in the Ugandan region, where $\mathrm{N}$-fixation was high and considered an important $\mathrm{N}$ source (Hecky, 1993). N-fixation was especially high under optimal light conditions in shallow water with shallow mixed depths (Mugidde et al., 2003; Guildford et al., 2003). Possibly the low abundances of $\mathrm{N}$-fixers we found might be an indication that light conditions in Mwanza Gulf were less optimal for N-fixers compared to other parts of Lake Victoria.

The degree of light limitation in our study was probably biased, as we estimated mixed depths from temperature profiles measured in the mornings when diurnal stratification was strongest. Complete mixing of the water column would probably occur once a day in the late afternoon, resulting in deeper mixed depths over much of the day. To demonstrate how much distances are affected by deeper mixing, we ran the light limitation analysis again with the original data, but assuming a $50 \%$ deeper mixed depths and using two alternative scenarios: (i) keeping the chlorophyll concentration per unit area over the mixed layer equal to the observed concen-

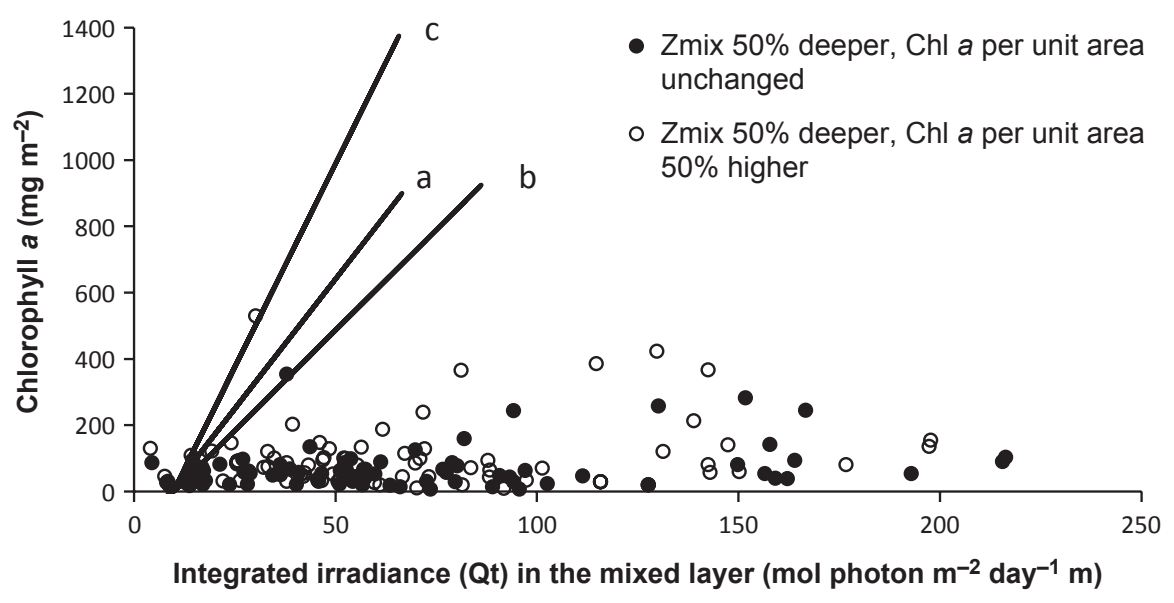

Fig. 9 Chlorophyll $a$ concentration per unit area and integrated light irradiance over mixed layer in Mwanza Gulf. The lines represent the maximum potential chlorophyll $a$ concentrations when light is limited (upper limit). Three lines were calculated: (a) based on the original data (for data points see Fig. 5), (b) based on simulated data (black dots), assuming a $Z_{\text {mix }}$ of $50 \%$ deeper than observed but with chlorophyll $a$ concentrations per unit area equal to the observed values and (c) based on simulated data (open circles), assuming a $Z_{\text {mix }}$ of $50 \%$ deeper than observed, and with chlorophyll $a$ concentrations per unit area $50 \%$ higher than observed $Z_{\text {mix }}$ (i.e. assuming that the concentration chlorophyll per volume in the mixed depth remained equal). 
tration per unit area, assuming that the concentration per unit volume below the observed mixed depth is zero and thus resulting in lower concentrations per unit volume over the simulated mixed depths and (ii) keeping the chlorophyll concentration per unit volume over the mixed layer equal to the observed concentration per unit volume, which resulted in higher concentrations per unit area with the simulated deeper mixed depths (Fig. 9).

According to scenario (i), distances increased with 5\% on average (line b, black dots in Fig. 9), whereas in scenario (ii) distances increased with $46 \%$ on average (line c, open circles). This means that if we assume a greater mixed depth than in our measurements, in both scenarios, distances increase and therefore light limitation is less likely to occur than in our original calculations. Therefore, on a time scale of $24 \mathrm{~h}$, we most probably overestimated the importance of light limitation and thus underestimated the effect of other factors limiting phytoplankton biomass. Thus, our conclusions that other factors besides light might be limiting in the Mwanza Gulf are strengthened rather than diminished.

Several studies suggest that primary production in Lake Victoria might not increase further with eutrophication, because nutrients are in excess and light limits further phytoplankton biomass production (Silsbe et al., 2006; Sitoki et al., 2010). This may account for the highly eutrophic gulfs in the north with very high phytoplankton biomass, but our study shows that besides light, nutrients can be limiting in the Mwanza Gulf and phytoplankton production is likely to depend on specific local environmental conditions. A further increase in eutrophication could lead locally to higher chlorophyll $a$ concentrations under optimal light and mixing conditions. However, this does not mean that primary production and lake productivity will continue to increase at a similar rate, because photosynthetic efficiency decreases with chlorophyll $a$. (Silsbe et al., 2006). Eutrophication affects the whole of Lake Victoria, but its heterogeneous environment should be considered when assessing water quality and implementing measures to reduce eutrophication.

\section{Acknowledgments}

This work is part of the integrated project 'Exploitation or eutrophication as threats for fisheries? Disentangling social and ecological drivers of ecosystem changes in Lake Victoria (SEDEC)', supported by the Netherlands Organisation for Scientific Research (NWO/WOTRO) Grant Number W01.65.304.00. We thank Koos Vijverberg for his supervision, advise and comments on this manu- script and Andrea Downing for her comments and thoughts on this manuscript. We thank Theo Frank for his detailed analyses of the phytoplankton samples of Mwanza Gulf. We thank Klaas Gerber, Alex Mangassa, Gerardi Rajabu, Paulo and Emma for their valuable field assistance and support and all enthusiastic MSc students involved in the data collection for this manuscript. Special thanks to the Tanzanian Fisheries Research Institute (TAFIRI) in Mwanza for providing laboratory space and use of field equipment during this research.

\section{References}

Akiyama T., Kajumulo A.A. \& Olsen S. (1977) Seasonal Variation of plankton and physicochemical condition in Mwanza Gulf, Lake Victoria. Bulletin of Freshwater Fisheries Research Laboratory, 27, 48-61.

American Public Health Association (APHA) (2005) Standard Methods for the Examination of Water and Wastewater. American Public Health Association, Washington, DC.

Bailey-Watts A.E. (1974) The algal plankton of Loch Leven, Kinross. Proceedings of the Royal Society of Edinburgh Section B (Biology), 74, 135-156.

Chen C. \& Millero F. (1977) The use and misuse of pure water PVT properties for lake water. Nature, 266, 707-708.

Cózar A., Bergamino N., Mazzuoli S., Azza N., Brachini L., Dattilo A.M., et al. (2007) Relationships between wetland ecotones and inshore water quality in the Ugandan coast of Lake Victoria. Wetlands Ecology and Management, 15, 499-507.

Cózar A., Bruno M., Bergamino N., Úbeda B., Bracchini L., Dattilo A.M., et al. (2012) Basin-scale control on the phytoplankton biomass in Lake Victoria, Africa. PLoS One, 7, 1-9.

Dubinsky Z. \& Berman T. (1981) Light utilization by phytoplankton in Lake Kinneret (Israel). Limnology and Oceanography, 26, 660-670.

Gikuma-Njuru P. (2008) Physical and biogeochemical gradients and exchange processes in Nyanza Gulf and main Lake Victoria (East Africa). PhD Thesis, University of Waterloo, Waterloo.

Gikuma-Njuru P. \& Hecky R.E. (2005) Nutrient concentrations in Nyanza Gulf, Lake Victoria, Kenya: light limits algal demand and abundance. Hydrobiologia, 534, 131140.

Goudswaard K., Witte F. \& Katunzi E.F.B. (2008) The invasion of an introduced predator, Nile perch (Lates niloticus, L.) in Lake Victoria (East Africa): chronology and causes. Environmental Biology of Fishes, 81, 127-139.

Guildford S.J., Bootsma H.A., Fee E.J., Hecky R.E. \& Patterson G. (2000) Phytoplankton nutrient status and mean water column irradiance in Lakes Malawi and Superior. Aquatic Ecosystem Health \& Management, 3, 35-45.

Guildford S.J. \& Hecky R.E. (2000) Total nitrogen, total phosphorus, and nutrient limitation in lakes and oceans: 
is there a common relationship? Limnology and Oceanography, 45, 1213-1223.

Guildford S.J., Hecky R.E., Taylor W.D., Mugidde R. \& Bootsma H.A. (2003) Nutrient enrichment experiments in tropical Great Lakes Malawi/Nyasa and Victoria. Journal of Great Lakes Research, 29, 89-106.

Haande S., Rohrlack T., Semyalo R.P., Brettum P., Edvardsen B., Lyche-Solheim A., et al. (2011) Phytoplankton dynamics and cyanobacterial dominance in Murchison Bay of Lake Victoria (Uganda) in relation to environmental conditions. Limnologica, 41, 20-29.

Hecky R.E. (1993) The eutrophication of Lake Victoria. Verhandlungen der internationalen Vereinigung für theoretische und angewandte Limnologie, 25, 39-48.

Hecky R.E., Mugidde R., Ramlal P.S., Talbot M.R. \& Kling G.W. (2010) Multiple stressors cause rapid ecosystem change in Lake Victoria. Freshwater Biology, 55, 19-42.

Kizza M., Rodhe A., Xu C., Ntale H.K. \& Halldin S. (2009) Temporal rainfall variability in the Lake Victoria Basin in East Africa during the twentieth century. Theoretical and Applied Climatology, 98, 119-135.

Kling H.J., Mugidde R. \& Hecky R.E. (2001) Recent changes in the phytoplankton community of Lake Victoria in response to eutrophication. In: The Great Lakes of the World (GLOW): Food-Web, Health and Integrity (EdsMunawar M. \& Hecky R.E.) , pp. 47-65. Vol. Ecovision World Monograph Series. Backhuys Publishers, Leiden.

Koenings J.P. \& Edmundson J.A. (1991) Secchi disc and photometer estimates of light regimes in Alaskan lakes: effects of yellow color and turbidity. Limnology $\mathcal{E}$ Oceanography, 36, 91-105.

Kolding J., Van Zwieten P.A.M., O.C. MkumboSilsbe G. \& Hecky R.E. (2008) Are the Lake Victoria fisheries threatened by exploitation or eutrophication? Toward an ecosystem-based approach to management. In: The Ecosystem Approach to Fisheries (Eds G. Bianchi \& H.R. Skjoldal), pp. 309-354. CABI, Wallingford, UK.

Krause-Jensen D. \& Sand-Jensen K. (1998) Light attenuation and photosynthesis of aquatic plant communities. Limnology and Oceanography, 43, 396-407.

Langenberg V. (2008) On the limnology of Lake Tanganyika. PhD Thesis, Wageningen University, Wageningen.

Lehman J.T. \& Branstrator D.K. (1993) Effects of nutrients and grazing on the phytoplankton of Lake Victoria. Verhandlungen der internationale Vereinigung für theoretische und angewandte Limnologie, 25, 850-855.

Lehman J.T. \& Branstrator D.K. (1994) Nutrient dynamics and turnover rates of phosphate and sulfate in Lake Victoria, East Africa. Limnology and Oceanography, 39, 227233.

Loiselle S.A., Azza N., Cózar A., Bracchini L., Tognazzi A., Dattilo A., et al. (2008) Variability in factors causing light attenuation in Lake Victoria. Freshwater Biology, 53, 535545.
Loiselle S.A., Cózar A., Dattilo A., Bracchini L. \& Gálvez J.A. (2007) Light limitations to algal growth in tropical ecosystems. Freshwater Biology, 52, 305-312.

Lung'ayia H., M'harzi A., Tackx M., Gichuki J. \& Symoens J.J. (2000) Phytoplankton community structure and environment in the Kenyan waters of Lake Victoria. Freshwater Biology, 43, 529-543.

Lung'ayia H., Sitoki L. \& Kenyanya M. (2001) The nutrient enrichment of Lake Victoria (Kenyan waters). Hydrobiologia , 458, 75-82.

Machiwa J. (2010) Stable carbon and nitrogen isotope signatures of organic matter sources in near-shore areas of Lake Victoria. Journal of Great Lakes Research, 36, 1-8.

Macintyre S., Romero J.R. \& Kling G.W. (2002) Spatialtemporal variability in surface layer deepening and lateral advection in an embayment of Lake Victoria, East Africa. Limnology and Oceanography, 47, 656-671.

Mazzuoli S., Loiselle S.A., Hull V., Bracchini L. \& Rossi C. (2003) The analysis of the seasonal, spatial, and compositional distribution of humic substances in a subtropical shallow lake. Acta Hydrochimica et Hydrobiologica, 31, 461-468.

Moed J.R. \& Hallegraef G.M. (1978) Some problems in the estimation of chlorophyll and phaeopigments from preand postacidification spectrometric measurements. International Review of Hydrobiology, 63, 787-800.

Morel A. (1988) Optical modeling of the upper ocean in relation to its biogenous matter content (case-I waters). Journal of Geophysical Research, 93, 10749-10768.

Morel A. \& Prieur L. (1977) Analyses of variations in ocean color. Limnology E Oceanography, 22, 709-722.

Mugidde R. (1993) The increase in phytoplankton primary production and biomass in Lake Victoria (Uganda). Verhandlungen der internationale Vereinigung für theoretische und angewandte Limnologie, 25, 846-849.

Mugidde R. (2001) Nutrient status and planktonic nitrogen fixation in Lake Victoria. PhD Thesis, University of Waterloo, Waterloo, Canada.

Mugidde R., Hecky R.E., Hendzel L.L. \& Taylor W.D. (2003) Pelagic nitrogen fixation in Lake Victoria (East Africa). Journal of Great Lakes Research, 29, 76-88.

Mwebaza-Ndawula L. (1994) Changes in relative abundance of zooplankton in northern Lake Victoria, East Africa. Hydrobiologia, 272, 259-264.

Myanza O.I., Rutagemwa D.K. \& Mwanuzi F.L. (2005) Non-point pollution loading in tanzania. In: Tanzania National Water Quality Synthesis Report (Ed. F.L. Mwanuzi), pp. 67-90. Lake Victoria Environmental Monitoring Programme (LVEMP), Dar es Salaam, Tanzania.

Ngupula G., Mbonde A. \& Ezekiel C. (2011) Spatial and temporal patterns of phytoplankton abundance and composition in three ecological zones in the Tanzanian waters of Lake Victoria. African Journal of Aquatic Science, 36, 197-206. 
Ngupula G.W., Ezekiel C.N., Kimirei I.A., Mboni E. \& Kashindye B.B. (2012) Physical and chemical characteristics of the Tanzanian inshore and offshore waters of Lake Victoria in 2005-2008. African Journal of Aquatic Science, 37, 339-345.

Nicholson S.E. \& Yin X.G. (2002) Mesoscale patterns of rainfall cloudiness and evaporation over the Great Lakes of East Africa. In: East African Great Lakes: Limnology, Palaeolimnology and Biodiversity. (Eds E.O. Odada \& D.O. Olago), pp. 93-119. Kluwer Academic Publishers, Dordrecht.

North R.L., Guildford S.J., Smith R.E.H., Twiss M.R. \& Kling H.J. (2008) Nitrogen, phosphorus, and iron colimitation of phytoplankton communities in the nearshore and offshore regions of the African Great Lakes. Verhandlungen der internationale Vereinigung für theoretische und angewandte Limnologie, 30, 259-264.

Okello W., Portmann C., Erhard M., Gademann K. \& Kurmayer R. (2010) Occurrence of microcystin-producing cyanobacteria in Ugandan freshwater habitats. Environmental Toxicology, 25, 367-380.

Preisendorfer R.W. (1986) Eyeball optic of natural waters: Secchi disk science. NOAA Tech. Memo. ERL PMEL 67. $90 \mathrm{pp}$.

Présing M., Herodek S., Preston T. \& Vörös L. (2001) Nitrogen uptake and the importance of internal nitrogen loading in Lake Balaton. Freshwater Biology, 46, 125-139.

Shayo S.D., Lugomela C. \& Machiwa J.F. (2011) Influence of land use patterns on some limnological characteristics in the south-eastern part of Lake Victoria, Tanzania. Aquatic Ecosystem Health and Management, 14, 246-251.

Silsbe G.M. (2004) Phytoplankton production in Lake Victoria, East Africa. MSc Thesis, University of Waterloo, Waterloo, Canada.

Silsbe G.M., Hecky R.E., Guildford S.J. \& Mugidde R. (2006) Variability of chlorophyll $a$ and photosynthetic parameters in a nutrient-saturated tropical great lake. Limnology and Oceanography, 51, 2052-2063.

Sitoki L., Ezekiel C., Wanda F., Mkumbo O.C. \& Marshall B.E. (2010) The environment of Lake Victoria (East Africa): current status and historical changes. International Review of Hydrobiology, 95, 209-223.
Stager J.C., Hecky R.E., Grzesik D., Cumming B.F. \& Kling H. (2009) Diatom evidence for the timing and causes of eutrophication in Lake Victoria, East Africa. Hydrobiologia, 636, 463-478.

Talling J.F. (1966) The annual cycle of stratification and phytoplankton growth in Lake Victoria (East Africa). Internationale Revue der gesamten Hydrobiologie, 51, 545621.

Tamatamah R.A., Hecky R.E. \& Duthie H.C. (2005) The atmospheric deposition of phosphorus in Lake Victoria (East Africa). Biogeochemistry, 73, 325-344.

Verschuren D., Johnson T.C., Kling H.J., Edgington D.N., Leavitt P.R., Brown E.T., et al. (2002) History and timing of human impact on Lake Victoria, East Africa. Proceedings of the Royal Society B: Biological Sciences, 269, 289-294.

Vlieghe P. (2000) Lake pollution and vulnerability of fishing communities. MSc Thesis, Eindhoven University of Technology, Eindhoven.

Wanink J.H., Katunzi E.F.B., Goudswaard K.P.C., Witte F. \& Densen W.L.T. (2002) The shift to smaller zooplankton in Lake Victoria cannot be attributed to the 'sardine' $R a$ strineobola argentea (Cyprinidea). Aquatic Living Resources, 15, 37-43.

Winberg G.G. (1971) Symbols, Units and Conversion Factors in Studies of Fresh Water Productivity. International Biological Programme, London.

Witte F., Goldschmidt T., Wanink J.H., Van Oijen M., Goudswaard K., Witte-Maas E., et al. (1992) The destruction of an endemic species flock quantitative data on the decline of the haplochromine cichlids of Lake Victoria. Environmental Biology of Fishes, 34, 1-28.

Witte F. \& Van Densen W.L.T. (1995) Fish Stocks and Fisheries of Lake Victoria. A Handbook for Field Observations. Samara Publishing Limited, Dyfed.

Yasindi A.W. \& Taylor W.D. (2003) Abundance, biomass and estimated production of planktonic ciliates in Lakes Victoria and Malawi. Aquatic Ecosystem Health and Management, 6, 289-297.

(Manuscript accepted 5 September 2013) 